\title{
Peningkatan Penguasaan Kosa Kata Siswa SD Melalui Penggunaan Media Boneka Tangan
}

\section{Sigit Widiyarto}

Universitas Indraprasta PGRI Jakarta

Muhammad Rusdianto

Universitas Indraprasta PGRI Jakarta

Paryono

Universitas Indraprasta PGRI Jakarta

\begin{abstract}
Abstrak
Penguasaan kosa kata sangat penting bagi siswa Sekolah Dasar. Pada usia 7-13 tahun, anak mampu menguasai kosa kata dengan baik. Namun tingkat penguasaan kosa kata anak masih rendah dan guru masih menggunakan media yang kurang tepat, bahkan tidak mempergunakan media di kelas,sehingga siswa kurang tertarik. Penelitian ini bertujuan untuk mengujiefektifitas pemakaian media boneka tangan dan pengaruh media boneka tangan pada penguasan kosa kata . Penelitian ini memakai rancangan eksperimen yang dilakukan pada satu kelompok saja tanpa kelompok pembanding (The One Group Pratest Posttest).Subyek penelitian Siswa SD ,dengan sampel data sebanyak 25 siswa. Data diolah dengan SPSS 22. Hasil penelitian menunjukkan pada,Uji Normalitas ,Homogenitas dan $\mathrm{T}$ Sampel Berpasangan dengan tingkat signifikan $\alpha=5 \%$, Hasil uji normalitas didapat nilai KolmogorofSmirnov iSig.0.200, dan Shapiro-Wilk 0.822 sehingga pada $\alpha=$ $5 \%=0.05<$ Sig. $=0$, sampel data berasal dari distribusi normal. Pada Uji Homogenitas Varians Levene Nilai Sig. 0.896, pada tingkat signifikansi $\alpha=5 \%=0.05<$ Sig.0.896 sehingga dapat dikatakan sampel data berasal dari varians yang Homogen, ,dapat disimpulkan pada tingkat kepercayaan 95\%,rata-rata kemampuan kosa kata setelah perlakuan dengan memakai media boneka tangan (mean sebesar 66.98640 ) dibanding sebelum memakai media ( mean sebesar 63.7240), naik sebesar 3.26240. Dengan kata lain, pemakaian media boneka tangan berpengaruh signifikan pada tingkat kepercayaan 95\%. Penelitian ini memberikan saran untuk mengatasi masalah yang ditemukan dalam penelitian.
\end{abstract}

Kata kunci: Penguasaan Kosa Kata, Media Boneka Tangan 


\section{Pendahuluan}

Pendidikan yang bermutu merupakan keniscayaan.Lembaga pendidikan mempunyai kewajiban untuk mengadakan pendidikan yang berkualitas.Pendidikan yang berkualitas akan menjadikan generasi yang siap dalam menghadapi era kompetisi yang makin cepat dan melahirkan pemimpin yang berkualitas. Pendidikan juga harus dilakukan secara konsisten ,yang meliputi inovasi,pengembangan terus menerus kearah yang lebih baik,proktif dan progresif.

Inovasi pembelajaran dan pemakaian media yang tepat serta bervariasi dikelas sangat mendukung, pada upaya peningkatan mutu pendidikan. Media yang dapat digunakan oleh guru di kelas,dapat membantu keberhasilan pembelajaran di kelas. Peran guru ikut andil dalam peningkatan mutu pendidikan. Guru dituntut dapat mengembangkan metode dan media pembelajaran yang dapat dipergunakan di kelas .

Media pembelajaran sebagai alat untuk membantu guru dalam kegiatan mengajar (teaching aids). Alat bantu mengajar yang mula-mula digunakan adalah alat bantu visual seperti gambar, model, grafis atau benda nyata lain. Alat-alat bantu itu dimaksudkan untuk memberikan pengalaman lebih konkrit, memotivasi serta mempertinggi daya serap dan ingat siswa dalam belajar. Media pembelajaran dapat diukur berdasarkan dua aspek yang menunjukan keefektivan pelaksanaan proses instruksional, yang diantaranya: bukti-bukti empiris mengenai hasil belajar siswa serta buktibukti yang menunjukan besarnya kontribusi (sumbangan) media atau media program terhadap keberhasilan dan keefektifan proses instruksional(Arsayd, Azhari. 2009 : 170).

Kosakata sebagai salah satu materi pembelajaran bahasa Indonesia di sekolah menempati peran yang sangat penting sebagai dasar penguasaan siswa terhadap penguasaan dalam materi mata pelajaran bahasa Indonesia dan penguasaan mata pelajaran lainnya. Penguasaan kosakata akan mempengaruhi cara berpikir dan kreativitas siswa dalam proses pembelajaran bahasa sehingga penguasaan kosakata dapat menentukan kualitas seorang siswa dalam berbahasa (Kasno, 2014:1) . Kualitas keterampilan berbahasa seseorang tergantung pada kuantitas kosakata yang dimilikinya. Makin banyak kosakata yang dimiliki seseorang, makin besar pula keterampilan berbahasanya.

Hal tersebut, tentunya dapat dipahami bahwa kualitas dan kuantitas kosakata atau pembendaharaan kata yang dimiliki siswa akan membantu siswa tersebut dalam menyerap berbagai informasi yang disampaikan para pengajar atau informasi dari berbagai sumber belajar lainnya. Penguasaan kosakata yang baik sangat mempengaruhi kemampuan siswa dalam berkomunikasi, baik lisan maupun tulisan.

Pentingnya pembelajaran kosakata terhadap peningkatan dan pengembangan kemampuan siswa berbahasa menyebabkan pembelajaran bahasa semakin mendesak untuk dilakukan secara lebih serius dan terarah. Hal ini dikarenakan dilapangan masih banyak dijumpai siswa -siswa yang mengalami kesulitan dalam melakukan pembelajaran bahasa Indonesia terutama tampak pada saat pembelajaran empat keterampilan berbahasa 
(menyimak, berbicara, membaca dan menulis) yang disebabkan kemampuan penguasaan kosakata Indonesia siswa rendah.

Kenyataan masih rendahnya penguasaan kosakata bahasa Indonesia sudah pernah diteliti oleh Yuharto pada siswa kelas III SDN Prabumulih II, Kecamatan Muara lakitan, kabupaten Musi Rawas, Sumatera Selatan. Berdasarkan observasi awal dan wawancara dengan beberapa siswa dan guru bahasa Indonesia di sekolah tersebut ditemukan bahwa secara umum siswa mengalami kesulitan dalam menerima dan mengungkapkan gagasan, ide, pikiran, dan perasaan, baik melalui tulisan maupun lisan dalam bahasa Indonesia disebabakan kosakata siswa yang terbatas dan juga dilihat dari hasil belajar beberapa ulangan harian tentang penguasaan kosakata dari 40 siswa hanya $25 \%$ yang memenuhi kriteria ketuntasan minimal. Permasalahan ini tentunya juga sangat berkaitan dengan keaktifan siswa dalam komunikasi menggunakan bahasa Indonesia.

Permasalahan atau kendala selanjutnya yang menjadi penyebab rendahnya kosakata siswa dalam pembelajaran bahasa Indonesia adalah penggunaan model, strategi dan teknik pembelajaran yang kurang tepat. Guru masih tetap menggunakan pendekatan ceramah yang lebih berpusat pada pengajar. Mereka mengajar hanya sesuai dengan langkah-langkah yang terdapat pada buku ajar, dan siswa tidak pernah melakukan pengamatan secara langsung terhadap keadaan nyata yang ada di sekelilingnya. Selain itu, proses pembelajaran masih menggunakan teknik menghafal (memorisasi).

Dengan landasan kurikulum, guru sebagai fasilitator berusaha mengembangkan strategi dan teknik pengajaran kosakata tersebut dengan cara-cara yang menyenangkan dan sesuai dengan karakteristik anak usia dini Guru dalam melakukan kewenangan profesionalnya, gurudituntut memiliki seperangkat kemampuan (kompetensi) yang beraneka ragam (Marsudi Wahyu Isworo 2016:62). Guru sebaiknya mengetahui hal yang paling menyenangkan pada masa anak-anak .Salah satunya bermain. Melalui bermain anak dapat berinteraksi dengan teman, berkomunikasi secara lisan dan juga belajar bahasa yaitu menambah kosakata baru dari lawan mainnya. Seorang guru harus pandai menyikapi kebutuhan anak akan bermain. Mengingat anak adalah manusia yang kondisi pertumbuhan dan perkembangannya belum matang. Jadi anak berbeda dengan orang dewasa. Pembelajaran dikelas diharapkan dapat dikerjakan oleh siswa bersama guru lebih efektif, kreatif, dan inovatif, sehingga siswa lebih bersungguh-sungguh, lebih memahami, dan menikmati proses pembelajaran bahasa dan sastra Indonesia di kelas sebagai kegiatan belajar-bermain.

\section{Metode}

Populasi studi adalah semua siswa SDN IX Jatiasih Kota Bekasi,dengan menggunakan teknikRandom Sampling. Populasi penelitian sebanyak 124 siswa. Responden dalam penelitian ini adalahsiswa sebanyak 25 anak yang duduk di bangku kelas 1 tahun ajaran 2016/2017. Waktu penelitian pada bulan Oktober sampai dengan Desember 2016. Tujuan penelitian untuk mengetahui (1).Efektifitas pemakaian media Boneka tangan (puppet hand). (2).Pengaruh media boneka tangan pada penguasan kosa kata.Penelitian ini memakai rancangan eksperimen yang dilakukan pada satu kelompok saja 
tanpa kelompok pembanding (The One Group Pratest Posttest).Model ini lebih sempurna karena sudah menggunakan tes awal (pratest) kemudian setelah diberikan perlakukan dilakukan pengukuran (posttest) untuk mengetahui akibat dari perlakuan (treatment), sehingga besarnya efek dari eksperimen dapat diketahui dengan pasti. Instrumen yang digunakan berbentuk tes penguasaan kosakata( Tema: Alam sekitar dan tubuh), baik sebelum dan sesudah dilakukan perlakukan (treatment) pemakaian media boneka tangan.Data dilakukan uji normalitas dan Homogenitas serta memakai Uji-t (One Sample t Test). Penghitungan memakai SPSS 22. Skema dari model penelitian adalah:

Tabel 1. Skema Rancangan Penelitian

\begin{tabular}{|c|c|c|}
\hline T1 & X & T2 \\
\hline Pretest & Treatment & Posttest \\
\hline
\end{tabular}

Keterangan :

$\mathrm{T}_{1}$ : Tes awal yang diberikan pada kelas eksperimen di awal penelitian $\mathrm{X}$ : Perlakuan yang diberikan pada kelas eksperimen: memakai media Boneka

$\mathrm{T}_{2}$ : Tes akhir yang diberikan pada kelas eksperimen di akhir penelitian

\section{Hasil}

Pengolahan pada SPSS 22 dapat dilihat pada tabel 2 dibawah ini:

Tabel.2. Tabel Normalitas

Tests of Normality

\begin{tabular}{|c|c|c|c|c|c|c|}
\hline \multirow{2}{*}{} & \multicolumn{3}{|c|}{ Kolmogorov-Smirnov ${ }^{\mathrm{a}}$} & \multicolumn{3}{c|}{ Shapiro-Wilk } \\
\cline { 2 - 7 } & Statistic & $\mathrm{df}$ & Sig. & Statistic & $\mathrm{df}$ & Sig. \\
\hline Nilai & .099 & 25 & $.200^{*}$ & .977 & 25 & .822 \\
\hline
\end{tabular}

*. This is a lower bound of the true significance.

Lilliefors Significance Correction

\section{Sumber : Output SPSS}

Pada tingkat signifikansi $a=5 \%$, kolom Kolmogorov-Smirnov (KS) pada tabel.2, , arena $\alpha=5 \%=0.05<$ Sig. $=0.200$, maka Ho tidak ditolak.

Pada tingkat signifikansi $a=5 \%$, kolom Shapiro-Wilk (SW) pada tabel.2,karena $\alpha=5 \%=0.05<$ Sig. $=0.822$, maka Ho tidak ditolak.

Dari uji KS dan SW dapat disimpulkan,karena Hoditerima maka asumsi bahwa sampel data berasal dari distribusi normal. 
Tabel.3 Uji Homogenitas Varians Levene

Test of Homogeneity of Variances

nilai

\begin{tabular}{|c|c|c|c|}
\hline $\begin{array}{c}\text { Levene } \\
\text { Statistic }\end{array}$ & $\mathrm{df} 1$ & $\mathrm{df2}$ & Sig. \\
\hline .017 & 1 & 48 & .896 \\
\hline
\end{tabular}

\section{Sumber : Output SPSS}

Tingkat signifikansi $\alpha=5 \%$,pada tabel 3, kolom Sig. Karena $\alpha=5 \%=0.05$ $<$ Sig.0.896 ,maka H0 tidak ditolak,dengan kata lain,asumsi homogenitas varians dapat terpenuhi.

Tabel. 4. Statistik Sampel Berpasangan

Paired Samples Statistics

\begin{tabular}{|ll|c|r|r|c|}
\hline & & & & \multicolumn{1}{c|}{$\begin{array}{c}\text { Std. } \\
\text { Deviation }\end{array}$} & $\begin{array}{c}\text { Std. Error } \\
\text { Mean }\end{array}$ \\
\hline Pair & Nilai_sebelum_media & 63.7240 & 25 & 8.41057 & 1.68211 \\
1 & Nilai_sesudah_media & 66.9864 & 25 & 8.66860 & 1.73372 \\
\hline
\end{tabular}

Sumber : Output SPSS.

Pada tabel 4, diatas tertera rata-rata nilai sebelum pemakaian media sebesar 63.240 dengan standard deviasi sebesar 8.41057,sedangkan nilai sesudah pemakaian media sebesar 66.9864.dengan standard deviasi sebesar 1.73372.

Tabel 5. Uji T Sampel Berpasangan

\begin{tabular}{|c|c|c|c|c|c|c|c|c|}
\hline \multicolumn{9}{|c|}{ Paired Samples Test } \\
\hline & \multicolumn{5}{|c|}{ Paired Differences } & \multirow[b]{3}{*}{$\mathrm{t}$} & \multirow[b]{3}{*}{$\mathrm{df}$} & \multirow{3}{*}{$\begin{array}{l}\text { Sig. (2- } \\
\text { tailed) }\end{array}$} \\
\hline & \multirow[b]{2}{*}{ Mean } & \multirow{2}{*}{$\begin{array}{c}\text { Std. } \\
\text { Deviation }\end{array}$} & \multirow{2}{*}{$\begin{array}{l}\text { Std. Error } \\
\text { Mean }\end{array}$} & \multicolumn{2}{|c|}{$\begin{array}{l}95 \% \text { Confidence } \\
\text { Interval of the } \\
\text { Difference }\end{array}$} & & & \\
\hline & & & & Lower & Upper & & & \\
\hline $\begin{array}{l}\text { Pair } 1 \\
\text { sebelum } \\
\text { sesudah }\end{array}$ & $\begin{array}{r}- \\
3.262 \\
40\end{array}$ & 2.36967 & .47393 & -4.24055 & -2.28425 & -6.884 & 24 & .000 \\
\hline
\end{tabular}

Sumber : Output SPSS.

Berdasarkan hasil tabel 5, Uji T Sampel Berpasangan dengan tingkat signifikan $\alpha=5 \%$, pada tabel. 5 , kolom $\mathrm{t}$ dan df,diperoleh $\mathrm{t}=-6.884 \mathrm{dan} \mathrm{df}=$ 24.Dari tabel t diperolehnilai t 0.05;24 $=1.780$. Karena $t=-6.994<-\mathrm{t} 0.05 ; 24$ $=-1.780$, maka Ho ditolak.Pada kolom Sig.( 2-tailed) tabel Uji T Sampel ,karena digunakan hipotesis satu sisi ( $\mathrm{H} 1: \mu 1-\mu 2<0$ atau $\mathrm{H} 1: \mu 1<\mu 2$, maka $0.000: 2=0$, maka $0.05>$ Sig. $=0$, maka Ho ditolak.

Pengambilan keputusan dengan cara diatas dapat diperoleh hasil yang sama yakni H0 ditolak. Hal tersebut dapat disimpulkan pada tingkat kepercayaan 95\%,rata-rata kemampuan kosa kata setelah perlakuan dengan memakai 
media boneka tangan (mean sebesar 66.98640 )dibanding sebelum memakai media (mean sebesar 63.7240),naik sebesar 3.26240. Dengan kata lain,pemakaian media boneka tangan berpengaruh signifikan pada tingkat kepercayaan $95 \%$.

\section{Pembahasan}

Penelitian dimulai pada awal Oktober 2016. Sebagai guru di SD IX peneliti melakukan observasi .Observasi meliputi kemampuan berbicara,menulis,membaca dan menyimak siswa kelas 1. Dari 25 siswa, hanya 10 anak yang mampu membaca dengan baik. Peneliti didampingi guru kelas (Hanny,S.Pd) ikut mengamati dikelas . Adapun tema yang diajarkan adalah alam sekitar dan tubuh . Pada pembelajaran diberikan cerita/dongeng dengan memakai alat peraga boneka tangan. Siswa sangat antusias dan bersemangat untuk mendengarkan dan ikut berbicara serta mengutarakan pendapat. Siswa diberikan kesempatan untuk berbicara seluas-luasnya. Pada awal penelitian, dibantu oleh guru kelas, peneliti memberikan tes lisan dan tulis kepada siswa. Setelah dilakukan pembelajaran sselama 6 sesi , peneliti melakukan tes penguaasaan kosakata yang bertema alam sekitar dan tubuh. Hasil yang didapat t pada tingkat kepercayaan 95\%,rata-rata kemampuan kosa kata setelah perlakuan dengan memakai media boneka tangan (mean sebesar 66.98640 ) dibanding sebelum memakai media ( mean sebesar 63.7240 ), naik sebesar 3.26240. Dengan kata lain, pemakaian media boneka tangan berpengaruh signifikan pada tingkat kepercayaan $95 \%$.

\section{Kesimpulan}

Data yang sudah diolah berdistribusi normal begitupula dengan uji homogenitas Varians Levene ,data bervarian homogen. Berdasarkanpembahasan diatas dapat disimpulkan sebagai berikut :1). Pemakaian media boneka tangan (puppet hand)sangat efektif pada peningkatan penguasaan kosa kata.2). Pemakaian media boneka tangan berpengaruh signifikan pada penguasaan kosa kata. Setelah pemakaian media boneka tangan , ada kenaikan sebesar 3.26240.

\section{Saran}

Pemakaian media yang tepat dan bervariasi sangat berperan pada peningkatan penguasaan kosa kata.Siswa lebih antusias dan termotivasi untuk mengungkapkan kata-kata dan kalimat. Pemakaian media boneka tangan data menjadi media yang menarik dan dapat meningkatkan penguasaan kosa kata. Guru sekolah Taman Kanak kanak dan dasar hendaknya dapat menggunakan media pengajaran sesuai dengan umur dan situasi lingkungan, serta materi atau tema yang ada di dalam kurikulum.

Media Boneka tangan dapat menjadi media alternatif yang dapat dipakai di Taman kanak-kanak. Siswa Sekolah dasar, terutama kelas bawah ( kelas 1, 2 dan 3) guru kelas dapat mempergunakan. Guru yang dapat mengubah 
suasana kelas menjadi aktif dan menarik, pasti akan membuat siswa termotivasi untuk belajar tanpa paksaan dan beban.

Media boneka tangan sebaiknya dapat jugadipergunakan oleh para orang tua siswa. Pemakaian media tidak hanya di sekolah melainkan di rumah, sebab dapat membantu mempercepat penguasaan perbendaharaan kata anak. Media ini dapat dipergunakan pada saat berbicara dengan boneka anak. Anakakan mengeluarkan ide-ide dan pemikirannya secara bebas sehingga melatih keterampilan menggunakan bahasa untuk berkomunikasi.

\section{Referensi}

Arsayd, Azhari. (2009). Media Pembelajaran. Jakarta: PT. RajaGrafindo .

Emzir.(2013),Metodologi Penelitian. Jakarta: PT.Raja Grafindo.

Kisworo Wayu Marsudi. (2016).Revolusi Mengajar Pembelajaran Aktif, Kreatif, Efektif Menyenangkan (PAKEM). Jakarta: Asyik Generation.

Kasno.(2004).Kamus sebagai Sumber Rujukan dan Pengajaran Kosakata. Jakarta:

Pramesti Getut.(2014).Kupas Tuntas Data Penelitan dengan SPSS 22 cetakan ke tiga. Jakarta.PT Elek Media Komputindo.

Santoso Singgih.(2015).SPSS 20 Pengolah Data Statistik di Era ,Jakarta. PT Elek Media Komputindo.

Yuharto.(2014). Peningkatan Penguasaan Kosa kata Bahasa Indonesia Melalui teknik Permainan Bahasa di Kelas III SD Negeri PrabumulihII Kec.Muara Lakitan Kab.Musi Rawas,Skripsi. Diterbitkan. Jakarta . Universitas Negeri Jakarta. 